\title{
Vuoden 1968 kapina
}

Kymmenen vuotta sitten, maaliskuun 22. päivänä vuonna 1968, miehittivät Nanterren enragés - raivopäät - yliopiston hallintorakennuksen, julistivat luentoboikotin ja aloittivat loppumattoman keskustelusarjan yliopistoreformista ja opiskelijoiden asemasta, Vietnamin sodasta ja kapitalismista. Parin kuukauden kuluttua ylioppilaat ja työläiset olivat kaduilla. Renault, Citroen, SudAviation olivat lakossa, barrikadeja pystytettiin ja otettiin yhteen mellakkapoliisin kanssa. Gaullistinen Ranska järkkyi.

Ranska ei ollut ainoa. Ylioppilaskapinoita oli Saksan Liittotasavallassa, Italiassa, USA:ssa, Englannissa, Japanissa, Espanjassa ja Pohjoismaissa, kaikkiaan ainakin kahdessakymmenessä maassa. Ylioppilaskapinat yhdistyivät usein työläisten lakkoliikkeeseen, mustien kansalaisoikeusliikkeeseen ja erilaisten alistettujen ja sorrettujen spontaaneihin joukkoliikkeisiin. Tapahtumien äkillinen voima oli kaikille enemmän tai vähemmän yllätys. Niinpä monet ensi arviot olivat hämmästyttäviä. Meillä Suomessa erään taantumuksellisen aikakauslehden päätoimittaja väitti, että ylioppilaiden kapina oli järjestetty ja rahoitettu jostain Itävallassa sijaitsevasta keskuksesta. Yleisradion kirjeenvaihtaja esitti Ranskan toukokuusta tulkinnan, että Kiina oli komentanut ylioppilaat kadulle sabotoidakseen Vietnamin rauhanneuvotteluja. Lehtien yleisönosastoissa kirjoitettiin ja kahvipöytäkeskusteluissa puhuttiin aivan mitä sattui. Loppuvuodesta kapinasta kirjoitettiin artikkeleita ja pamfletteja kuin Pariisin kommuunista aikanaan, suurin osa heikkoja ja neuvottomia.

Tuskin paljon liioitellaan, jos sanotaan vuoden 1968 kuuluvan niihin vuosiin, jollaisista Marx kerran sanoi, että niihin keskittyy kahdenkymmenen tavallisen vuoden kehitys.

Porvarillinen historiankirjoitus on vanhastaan kutsunut vuoden 1848 porvarillis-demokraattisia vallankumoustapahtumia Euroopassa nimellä "hullu vuosi". Kymmenen vuotta sitten mielikuvituksettomat lehtimiehet leimasivat myös vuoden 1968 "'hulluksi vuodeksi". Mutta niin erilaisia kuin vuodet 1848 ja 1968 ovatkin, eivät ne kumpikaan ole mitään hulluja, vaan viisaita vuosia. Vuonna 1848 eteni porvarillis-demokraattinen kehitys ennennäkemättömällä tavalla, ja tieteellinen sosialismi syntyi. Vuonna 1968 ravisteltiin näennäisesti vakiintuneen kapitalismin kulisseja, ja opiskelijat ja sivistyneistö astuivat politiikan areenalle edistyksellisenä voimana. Vuoden 1968 tapahtumissa ei sellaisenaan ole kovin paljon säilyttämistä tai vaalimista, mutta tärkeintä ei olekaan, millainen liike oli, vaan mitä liikkeestä hyvin pian tuli.

Laiskajärkiset ihmiset ja taantumukselliset ideologit kutsuivat sitä "hyvinvointikapinaksi"' tai "'kansainväliseksi muodiksi". Tällaiset selitykset eivät ole vielä sillä tasolla, että niitä voitaisiin kutsua edes pinnallisiksi. Vuoden 1968 purkaukseen vaikuttivat monet syvälliset aineelliset ja henkiset tekijät: kansainvälisen voimasuhteen muutos, uuskolonialismin viimeiset kouristukset, kapitalismin kriisin aineksien monipuolinen kärjistyminen kehittyneissä kapitalistisissa maissa. Monet tendenssit, jotka tuolloin olivat idulla, näkyvät tänä päivänä kaikkien silmiin. Tällä hetkellä kapitalismi on syvässä ja pysyvässä

kriisiä, autoritaarisuus nostaa päätään enemmän kuin "antiautoritaarisen liik- 
keen aikoina, demokraattinen yliopistoreformi on jäänyt tulematta, sivistyneistön taloudellisessa ja sosiaalisessa asemassa on tapahtunut jyrkkä huonontuminen jne. Kun ajattelemme tilannetta toisaalta vuonna 1968 ja toisaalta vuonna 1978, tekisi melkein mieli sanoa, että seuraukset tulivat kaikkien näkyville ensin, ja syyt vasta post festum.

Vuoden 1968 kapinallisiin voidaan ja kannattaa suunnata mitä ankarin teoreettinen ja poliittinen kritiikki. Teorian alalla kokoontuivat monenkirjavana kaleidoskooppina epäselvä "uusvasemmistolaisuus", frankfurtilaisuus, eksistentialismi, maolaisuus, trotskilaisuus, anarkismi, spontanismi jne. Poliittisesti hallitsi usko työväenjärjestöjen ja kaikkien instituutioiden ohi tapahtuvaan "suoraan toimintaan", opiskelijat ja sivistyneistö nähtiin usein messianistisena etujoukkona. Kaiken kaikkiaan: toiminta ja etiikka kulkivat edellä, teoria ja perustelut saivat tulla jäljessä. Kaikessa oli marcuselaisen Suuren Kieltäytymisen makua; se oli kosminen kapina ei ainoastaan kapitalismia, vaan kaikkea siihenastista sivilisaatiota, tekniikkaa ja esinemaailmaa vastaan. Reformismi ja äärivasemmistolaisuus löivät kättä toisilleen. Kapinallisten parhaimmistossakin sydän oli marxilainen, mutta järki porvarillinen.

Heikkouksistaan huolimatta - ja jopa itse heikkouksissaan - vuoden 1968 liike sisälsi paljon arvokasta. Kukaan ei voi asettaa kyseenalaiseksi kapinallisten motiivien vilpittömyyttä. He tekivät uhrautuvaa ja epäitsekästä työtä. Ja niin hämäriä kuin puheet "repressiivisestä toleranssista" tai "pitkästä marssista läpi myöhäiskapitalistisen yhteiskunnan instituutioiden" usein olivatkin myös puhujille itselleen, ei käy kiistäminen, että kapinalliset esittivät varsin hyvää porvarillisen demokratian ja porvarillisen kulttuurin kritiikkiä, usein parempaa kuin mitä myöhemmin on kuultu.

Vuoden 1968 kapinallisia ei enää ole, vaan he ovat hajautuneet luokkien ja puolueiden kesken; he ovat sirottuneet eri puolille yhteiskuntaa edustaen mitä erilaisimpia sosiaalisia tyyppejä ja intressejä. Monista kapinallisista, jotka kerran vannoivat kääntävänsä nurin koko kapitalismin, on tullut harmittomia pikkuporvareita ja reformistisia virkamiehiä tai sitten pomminheittäjiä ja "subversiivisia sosialisteja". Nämä tyypit edustavat kuitenkin kymmenen vuoden takaisen liikkeen sivuvirtauksia, oikealle ja äärivasemmalle. Kehityksen valtavirtaa on edustanut ja edustaa vuosikymmenen taitteesta lähtien muodostunut vallankumouksellinen ja demokraattinen opiskelijaliike ja siihen liittyen sivistyneistön edustajien vallankumouksellinen $\mathrm{j}$ a demokraattinen liike. Tutkijoiden, taiteilijoiden, kasvattajien, tiedottajien, lääkäreiden, teknikoiden ja muiden henkisen työn tekijöiden ryhmien keskuuteen on muodostunut uusi edistyksellinen ydinjoukko, joka viime vuosina on kasvanut sekä ulkoisesti että sisäisesti, sekä määrällisesti että laadullisesti.

Vuoden 1968 kapinan välitön teoreettinen anti on hyvin vähäinen. Erilaisten marxilaisina esiintyvien teoreetikkojen ja agitaattoreiden taso ja tietoisuus oli hyvin matalalla, poikkeuksena jokin Liittotasavallan SDS, jossa oli tiettyjä frankfurtilaisen "yliopistomarxismin" perinteitä. Kuten sanottu, kapinallisten 
sydän oli usein marxilainen ja järki porvarillinen. Mutta itse teoreettinen asenne, palava halu omaksua marxilaisuutta ja työväenliikkeen kokemuksia, johti tuloksiin. Ryhdyttiin syventymään marxilaiseen teoriaan, opiskeltiin vakavasti oman alan kysymyksiä, kiisteltiin, muodostettiin enemmän tai vähemmän heiveröisiä koulukuntia, alettiin kyetä tuottamaan marxilaista tutkimusta. Kehityksen kulussa, marxilaisuuden omaksumisen asteen syvetessä tuli välttämättömäksi vetää ne johtopäätökset, jotka aikamme marxilaisuudesta on vedettävä, niin teoreettisella kuin myös poliittisella ja moraalisella tasolla.

Näistä teoreettisista, poliittisista ja moraalisista johtopäätöksistä on Tutkijaliiton ydinjoukko syntynyt. Kuluneina vuosina olemme oppineet teoriaa ja tehneet tutkimusta, olemme kohottaneet tietoisuuttamme ja järjestäytyneisyyttämme. Kuluneiden vuosien muutos on luonteeltaan palautumaton. Mitään paluuta vuoteen 1968 tai sitä edeltävään tilanteeseen ei enää ole. Siitä huolimatta, että Suomessa on käytössä virkakiellon "kansallinen" muunnos, siitä huolimatta että marxilaisuutta monissa paikoissa pyritään työntämään akateemisten seinien ulkopuolelle, kaikesta tästä huolimatta Suomeen on pysyvästi muodostunut marxilainen tutkijakunta ja laaja demokraattinen tutkijaliike. Tutkijaliitto kokoaa riveihinsä näitä marxilaisia ja muita demokraattisia tutkijoita.

Liittomme järjesti 8. 4. 1978 seminaarin, jossa käytiin paneelikeskustelu aiheesta: "Onko Suomeen syntynyt marxilainen ja demokraattinen sivistyneistö?” Kysymys oli itse asiassa tarpeettoman retorinen. Tällainen sivistyneistö on tietenkin muodostunut; kysymys on vain siitä, mitä tällä sivistyneistöllä tehdään, ja mitä se itse tekee. Juuri tähän kysymykseen Tutkijaliitto kehittää päivittäin vastauksia. Tutkijaliitto on samanaikaisesti sekä demokraattinen tutkijayhteisö että edistyksellinen järjestöllinen voima, joka kytkee kohtalonsa työväenluokan vallankumoukselliseen liikkeeseen ja kaikkeen demokraattiseen joukkoliikkeeseen.

Vuoden 1968 kapinan perään on pantu monta pistettä. Tutkijaliitto on yksi näitä pisteitä. Tunnustamme samanaikaisesti sekä yhteytemme vuoden 1968 kapinaan että eromme siitä.

Tänä vuonna ilmestyy Suomessa varmasti useita kirjoituksia, joissa arvioidaan vuosikymmenen takaisia tapahtumia, niiden syitä ja seurauksia. Valtaosa näistä kirjoituksista ei valitettavasti tule olemaan kovin hyviä. Aivan liian paljon tulee ilmestymään toisaalta nostalgisia ja sentimentaalisia kirjoituksia, toisaalta pahanilkisyyttä ja lyhytnäköistä viisastelua tihkuvia tekstejä. Se on todella valitettavaa, sillä tällä hetkellä on periaatteessa täydet mahdollisuudet kirjoittaa hyviä arvioita viime vuosikymmenen lopun ja vuosikymmenen taitteen liikehdinnöistä. Välimatkaa on jo tarpeeksi, mutta mahdollisimman autenttinen lähdeaineisto on edelleen käsillä todella hyvän arvion laatimista varten. Tällainen arvio tarvitaan, ei suinkaan pelkän tapahtuneen rekisteröinnin vuoksi, vaan siten että lähtökohtana on nykyhetki - sen juuret ja luonne ja nykyisyyden sisältämät tulevaisuuden ainekset. 


\section{Tässä numerossa}

Kapitalismin kriisin syveneminen Suomessa edellyttää marxilaiselta ja edistykselliseltä tutkimukselta myös kriisiteorian ja kriisin konkreettisen erittelyn syventämistä. Tässä numerossa julkaisemme useita artikkeleita, joissa käsitellään nykyisen kriisin syitä ja ilmenemismuotoja. Sakari Hännisen ja Pekka Kososen aiheena on "Talouden rakennetekijät ja kriisi". Artikkelissa keskitytään tutkimaan kriisin rakenteellista perustaa Suomen taloudessa ja tehdään joukko tärkeitä huomautuksia TANDEM-tutkimukseen, TANDEM:in tapaan nähdä Suomen talouden ja talouspolitiikan erityispiirteet. Tärkeiden teoreettisten kysymysten parissa liikkuu myös Kari Toikka kirjoituksessaan "Poliittisen kriisin käsitteestä".

Kolme muutakin kirjoitusta liittyy välittömästi kriisiteemaan. Jyrki Jyrkämä ja Antti Kasvio ovat kirjoittaneet yhteenvedon aiheesta 'Työttömyys sosiaalitieteellisen tutkimuksen kohteena”. Jeja-Pekka Roos tarkastelee kriisiä elämäntapatutkimuksen näkökulmasta, aiheenaan "Kriisi, elämäntapa, onnellisuus". Teuvo Räty ja Bertel Ståhle selvittävät, miten nykyinen kriisi näkyy valtion tiedepolitiikassa, ennen kaikkea tutkimusrahoituksessa.

Numerossamme 3/1977 julkaisimme sarjan kirjoituksia evoluutioteoriasta. Teemaa jatkaa tässä numerossa prof. A. S. Severtsov artikkelillaan 'Evoluutioteoria ja dialektinen materialismi", jossa evoluutioteemaa laajennetaan yleistieteelliseen ja filosofiseen suuntaan. Prof. Severtsov on Moskovan valtionyliopiston evolutiikan professori, alan tunnettu asiantuntija. Hän on kirjoittanut artikkelinsa nimenomaan meidän lehteämme varten.

Mikä on UKTJ? Monet tietävät, että se on lyhenne sanoista "uusi kansainvälinen talousjärjestys". Mutta anteeksiantamattoman harvat tietävät, mitä UKTJ tarkkaan ottaen on, mikä on sen synty, sisältö ja merkitys. Turkulaiset kansainvälisen talouden ja politiikan asiantuntijat Jan Otto Andersson, Esko Antola ja Jyrki Käkönen selventävät UKTJ:tä artikkeleissaan.

Olemme aikaisemmissa numeroissamme eri yhteyksissä käsitelleet Suomen ja Neuvostoliiton välistä tieteellis-teknistä yhteistyötä. Jatkamme tässä numerossa. Suomen ja Neuvostoliiton tieteellis-teknisen yhteistyökomitean Suomea edustavana puheenjohtajana toimii ministeri Pekka Kuusi. Ministeri Kuusi on myöntänyt lehdellemme haastattelun aiheesta. 